\title{
高脂肪無糖質食搷取ラットにおける糖新生充進と
}

\author{
尿素生成との関連
}

\author{
高 瀬 幸 子 \\ 静岡女子大学家政学部食物学科
}

\section{Interrelationship between Gluconeogenesis and Ureogenesis in Rats Fed a High Fat, Carbohydrate-Free Diet}

\author{
Sachiko TAKASE \\ Department of Food and Nutrition, Faculty of Science of Living, \\ Shizuoka Women's University, Shizuoka, 422
}

Nippon Eiyō Shokuryō Gakkaishi (J. Jpn. Soc. Nutr. Food Sci.) 38, 109 116 (1985)

The study was carried out to observe the effects of high fat feeding on the metabolic pathway of gluconeogenesis as opposed to high protein feeding. The rats were fed on a high protein-carbohydrate free (HP) diet, a high fat-carbohydrate free diet consisting of either corn oil (HF-corn oil) or medium chain triglyceride (HF-MCT), and a control diet (high carbohydrate) for 10 days.

A high activity of hepatic glucose-6-phosphatase (G6Pase) was shown in the 3 groups except for the control group. Despite elevated gluconeogenesis in those groups, the activity of hepatic enzyme of glutamic alanine transaminase (GAT), pyruvate carboxylase (PC) and arginase was different between rats fed the HF-corn oil, HF-MCT and HP diets. The activities of GAT and arginase increased in the HP group, but PC activity did not increase in comparison with the control group. The HF-corn oil fed rats showed an enhancement of PC activity, but not GAT and arginase activity. The HF-MCT feeding, however, did not induce such a high activity of PC. It rather resulted in higher GAT and arginase activities than that observed with the HF-corn oil feeding, although the activities were less than that in rats fed the HP diet.

When animals were starved for 24 hours, the levels of G6Pase activity in rats of the 3 groups were decreased to almost the same level as in control rats. The findings concerning the relative activity of GAT and PC among the fed groups were even observed in the starved rat groups. Arginase activity was low in HF-corn oil and HF-MCT rats in starved state.

These results suggest that a different mechanism from the one occurring in high protein feeding is responsible for stimulating glucose synthesis by high fat (long chain) feeding, and that acetyl CoA, which is formed in large amounts as a result of accelerated fatty acid oxidation, may promote gluconeogenesis without ureogenesis acceleration.

(Received June 13, 1984)

糖新生系は解糖系ととむに常時働いていて，両者の働 きの平衡状態の傾きによってクルコース合成あるいは分 解が優先することになる1》。食餌から十分量の糖質が供 給されない場合は，その合成が優先して2)い゙，クルニー スは肝䑏から血中へ供給され血糖の佰常性が維持される ことはよく知られている。

Eisenstein ら5)は，高タンパク質-無糖質食はクルカ コン分泌を增加して肝のグルニース合成を高めるが，高 脂肪一無楉質食による糖新生元進には，そのようなホル モン分泌の増加を伴っていないと報告している。また，

于422 静岡市谷田 409
既報6)に示したように低糖質一高脂肪食を摄食した動物 では，高糖質一低脂肪食の動物に比へ， glucose-6-phosphatase 活性が上昇するのに, arginase 活性は低下し 尿中窒素排泄量の減少が観察され, 桾新生方進時には必 ずしも尿素生成が增大するとは限らないことが示唆され た。

このように, 肝鋮での糖新生え進に, 動物の摄取した 食餪組成が微妙に影響し, 関連のホルモン分泌レヘルや 律速醭素活性などの変動，さらにそれらと尿素生成との 阑は一様でないるのと思われる。

最近, 糖新生は尿妻生成と密接に関連していて, 糖新 
Table 1. Diet composition.

\begin{tabular}{|c|c|c|c|c|}
\hline \multirow[b]{2}{*}{ Ingredient } & \multirow[b]{2}{*}{ Control } & \multirow{2}{*}{$\begin{array}{c}\text { High-protein } \\
\text { (HP) }\end{array}$} & \multicolumn{2}{|c|}{ High-fat } \\
\hline & & & $\begin{array}{c}\text { Corn oil } \\
\text { (HF-corn oil) }\end{array}$ & $\begin{array}{c}\text { MCT } \\
(\mathrm{HF}-\mathrm{MCT})\end{array}$ \\
\hline Casein & 20 & 85 & 20 & 20 \\
\hline Sucrose & 65 & 0 & 0 & 0 \\
\hline Corn oil & 5 & 5 & 35 & 2 \\
\hline MCT oil a) & & & & 33 \\
\hline Cellulose powder $\left.{ }^{b}\right)$ & 5 & 5 & 40 & 40 \\
\hline Salt mixture $\left.{ }^{c}\right)$ & & & 4 & \\
\hline Vitamin mixture d) & & & 0.5 & \\
\hline Choline chloride & & & 0.5 & \\
\hline Calorie (kcal/100 g) & 385 & 385 & 395 & 395 \\
\hline
\end{tabular}

a) Medium chain triglyceride supplied by Ono Pharmaceutical Co., Osaka.

b) Toyo Roshi Co., Tokyo.

c) Harper's salt mixture purchased from Oriental Yeast Co., Ltd.

d) The following vitamins were made up to $100 \mathrm{~g}$ by adding glucose : vitamin A acetate, $434 \mathrm{mg}$; vitamin $\mathrm{D}_{2}, 65.0 \mathrm{mg}$; vitamin $\mathrm{E}$ acetate, $3.1 \mathrm{~g}$; vitamin $\mathrm{K}_{3}, 20 \mathrm{mg}$; niacine, $7.38 \mathrm{~g}$; inositol, $3.69 \mathrm{~g}$; pyridoxine- $\mathrm{HCl}, 260 \mathrm{mg}$; thiamine- $\mathrm{HCl}, 260 \mathrm{mg}$; riboflavin, $260 \mathrm{mg}$; calcium pantothenate, $550 \mathrm{mg}$.

生六進時には尿素生成も六進する7)8) とい5成績もみら れるが，逆の関係を示す報告9 もあり，一定の見解が得 られていないよらに思われる。それらの成績は一般に遊 離細胞や灌流肝を用いた実験成績が多く，in vivo での 観察は少ない。

そこで本研究では，高脂肪食による糖新生六進時の代 謝変動は高タンパク質食のそれと異なり，その違いが糖 新生と尿素生成との関連に影響を及ぼすのか否かを明ら かにするための検討を行なった。なお，高脂肪食の場合 にその脂肪酸の酸化を通して起こる代謝変動か，糖新生 と尿素生成との関連を支配することが考えられるので, 長鎖脂肪とは生化学的性質の異なる中鎖脂肪 (medium chain triglyceride, MCT ${ }^{10)}$ を用いた高脂肪食を対比さ せ観察した。また，それらの食餌の影響をよりはっきり 把握する意味で, 絶食ラットの以上の事柄についての検 討も加えた。

\section{実 験 方 法}

\section{1. 実験動物}

離乳直後の Wistar 系ラットを標隼固形飼料 MF（オ リエンタル酵母(侏) で3〜 4 日間予備飼育したのち, 動 物を 4 群に分け, 対照群に高糖質食群 (control) を, 試験群に高タンパク質食群 (HP) および高脂肪食群の corn oil 群 (HF-corn oil) と MCT 群 (HF-MCT) の 計 3 群をおいた。各群の餌料組成は Table 1 亿示した。 試験食群はいずれも無糖質食とした。

食慨および水は自由に与兄 10 日間飼育した。飼育期
間終了後，各群の動物を 2 分して，一方はただちに（摄 食ラット)，他方はさらに 24 時間絶食させたのち（絶食 ラット)，解剖に付した。その際，動物を午前 11 時から 12 時の間に断頭屠殺し, 血液と肝臓を採取した。その一 部をその日のうちに血糖值測定に供し, 残りは $-20^{\circ} \mathrm{C}$ に保存して血清遊離脂肪酸の測定に用いた。肝䯈は氷冷 生理食塩水で洗い付着物を取り除いた後，滤紙にて余分 の水分を拭き取り，全重量を秤量した。肝臓の半分を䤃 素液の調製に供し，残り半分をクリコーゲン測定に供す るまで $-20^{\circ} \mathrm{C}$ で保存した。

\section{2. 醭素活性の測定}

Glutamic alanine transaminase [EC 2.6.1.2, GAT] の酵素液としては, 約 $1 \mathrm{~g}$ の肝組織に $100 \mathrm{mM} ト$ ト 塩酸- $0.25 \mathrm{M}$ ショ糖液（pH 7.5）を加え $10 \%$ ホモジネ イトとした後， $10,000 \times g$ で 15 分間冾却遠心分離し， その上清画分を用いた。さらに，約 $2 \mathrm{~g}$ の肝組織に 10 倍容の $0.25 \mathrm{M}$ ショ糖液を用いてホモジナイズした後, $700 \times g, 10$ 分間冷却遠心分離した上清の $1 / 3$ を arginase [EC 3.5.3.1] 活性の測定に用い, 残りの上清 を再び $10,000 \times g$ で 15 分間遠心して得られた上清画分 を glucose-6-phosphatase [EC 3.1.3.9, G6Pase] 活性 測定に用いた。さらに沈塩を 5 倍容の水冷水を用いて木 モジナイズしたものを pyruvate carboxylase [EC 6.4. $1.1, \mathrm{PC}$ ] の醭素液とした。

G6Pase 活性は Segal らの方法 ${ }^{11}$ により測定し，反忘 により生成したりンを Fiske-SubbaRow 法を改良した Bartlett 法 ${ }^{12}$ により定量した。GAT 活性は Segal らの 
Table 2. Food intake and weight gain of rats fed control, high protein and high fat diets.

\begin{tabular}{lccc}
\hline Groups & $\begin{array}{c}\text { Initial body weight } \\
(\mathrm{g})\end{array}$ & $\begin{array}{c}\text { Weight gain } \\
(\mathrm{g})\end{array}$ & $\begin{array}{c}\text { Food intake } \\
(\mathrm{g} / \mathrm{day})\end{array}$ \\
\hline Control & $45 \pm 1^{\mathrm{a})}$ & $46 \pm 2$ & $9.3 \pm 0.6$ \\
HP & $45 \pm 1$ & $30 \pm 2^{* \mathrm{c})}$ & $6.3 \pm 0.4^{* * *}$ \\
HF-corn oil & $44 \pm 1$ & $41 \pm 1^{* *}$ & $8.5 \pm 0.4$ \\
HF-MCT & $45 \pm 1$ & $17 \pm 1^{* * *}$ & $5.2 \pm 0.8^{* * *}$ \\
\hline
\end{tabular}

a) Values are means \pm SEM for 14 animals in each group.

b) Weight gain after 10 days on the diets.

c) Values significantly different from the control, using $t$-test analysis : $* p<0.05 ; * * p<0.01$; $* * * p<0.001$.

方法 ${ }^{13)}$ により測定し，PC 活性はUtter らの方法 ${ }^{14)}$ に従 い測定した。それらは，反応系に共役させた酵素 (GAT は乳酸脱水素醳素, PC はリンゴ酸脱水素酵素) の反応 により消費された $\mathrm{NADH}$ 量を $340 \mathrm{~nm}$ での四光度の減 少により求めて酵素活性を測定した。arginase 活性は Schimke の方法 ${ }^{15)} に よ り$ 測定した。

酵素液のタンパク質量は Lowry 法 ${ }^{16)}$ によウシシ血清 アルブミンを標準として測定した。

\section{3. 血清グルコースおよび遊離脂肪酸量の測定}

血清グルコースは glucose oxidase 法17)によグルコ スタット（藤沢薬品㑣キット）を用いて定量した。血清 遊離脂肪量は久城らの方法 ${ }^{18)} に よ り$ 測定した。

\section{4. 肝グリコーゲンおよび遊離脂肪酸量の測定}

旰グリコーゲンは Seifter らの方法 ${ }^{19)}$ 一部修正して 定量した。精秤した $0.5 \mathrm{~g}$ 前後の肝組織を $30 \% \mathrm{KOH}$ を用いて加熱溶解し，定量的にその一部をとり $95 \%$ ア ルコールと $6 \% \mathrm{Na}_{2} \mathrm{SO}_{4}$ を用いて析出させ, フンスロン 試薬により比色定量した。

肝の遊離脂肪酸量の測定にあたり, Eisenstein らの方 法5) に従って精秤した $1 \mathrm{~g}$ 前後の肝組織に 5 倍容の $1 \%$ KCl-1 mM EDTA 溶液を加えてホモジナイズした。その 一部を希秎したものにつき血清に用いた同し方法により 脂肪酸量を測定した。

\section{実 験 結 果}

慨料掑取量と体重増加量は Table 2 飞示した。HP 群 と HF-MCT 群は, 飭料摂取量が少なく体重增加量も対 照群に比べ劣っていた。

1. 血糖値，血清遊離脂肪酸値および肝䑏のグリコー ゲンと遊離脂肪酸量

掑食ラットの血糖值は, 試験群の 3 群とも対照群に比 べ低い值を示し，とくに HF-MCT 群ではそれが顕著で あった。これらの血糖値の低下は，無糖質食の影響によ るるのと思われる。一方, 24 時間絶食により対照群, HP 群, HF-corn oil 群の 3 群では掟食時の $60 \sim 80 \%$
の血糖値に低下したが，HF-MCT 群では絶食による血 糖値の低下はみられず拱食ラットのそれと同じであった (Table 3)。

肝グリコーゲン量は，摂食ラットの場合に試験群の 3 群とも有意に少なく, とくに高脂肪食の 2 群は対照群の 1/3 以下であった。各群の動物は絶食によりほ之んどの 肝グリコーゲンを消費しわずかな量となった。注目され ることに, 試験群の 3 群とす絶食時の肝クリコーゲン量 は, 対照群に比べ有意に高値を示し約 $5 \sim 8$ 倍量であっ た (Table 3)。このことは Eisenstein $5^{5)}$ や Zaragoza

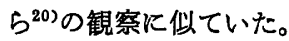

血清遊離脂肪酸値は, 統計的有意差ではないが, 摄食 ラットの HP 群で増加の傾向を示した (Table 3)。この 群では高タンパク質のためにグルカゴン分泌が六進し て ${ }^{5211}$ ，脂肪組織からの遊離脂肪酸の放出が高まる傾向 にある ${ }^{22)}$ と思われる。絶食時には，いずれの群の血清遊 離脂肪酸値も摄食時に比べ 1.5 2 倍に著しく增加した。 絶食時のそれらの値のらち HF-MCT 群は有意偪高い値 を示し, HP 群でも高値の傾向を示した（Table 3)。

肝遊離脂肪酸量は，摂食ラットの場合，HF-corn oil 群がどの群よりも高い値であった。 HP 群と HF-MCT 群のそれはほぼ同じ量であったが，対照群よりは高い值 であった (Table 3)。

\section{2. 糖新生系酵素の活性に及ぼす高脂肪食の影然} 高脂肪揸食の動物における糖新生過程の代謝変動に, 高タンパク質食の場合との違いがあるかを検討するた めに, 肝臓の G6Pase (Table 4), GAT (Fig.1), PC (Fig.2) の醭素活性を観察した。

掑食ラットの G6Pase 活性は, 試験群のいずれす有意 に高く, 対照群の約 1.3 1.5 倍の活性上昇を示した。 24 時間絶食により, それらの活性値は HF-MCT 群を 除いた 2 群（HP, HF-corn oil）では撕食ラットの約 80\%の活性值に低下した。HF-MCT 群の絶食ラットの G6Pase 活性は，摂食ラットの值とほぼ同じであった。 なお，絶食ラットの各群間の G6Pase 活性に有意差は認 
Table 3. Effects of high protein and high fat diets on serum glucose and free fatty acids (FFA), and liver glycogen and FFA.

\begin{tabular}{lcccc}
\hline \multicolumn{1}{c}{ Groups } & $\begin{array}{c}\text { Serum glucose } \\
(\mathrm{mg} / \mathrm{dl})\end{array}$ & $\begin{array}{c}\text { Serum FFA } \\
(\mu \mathrm{Eq} / l)\end{array}$ & $\begin{array}{c}\text { Liver glycogen } \\
(\mathrm{g} / 100 \mathrm{~g})\end{array}$ & $\begin{array}{c}\text { Liver FFA } \\
(\mu \mathrm{mol} / \mathrm{g})\end{array}$ \\
\hline Fed & & & & \\
Control & $187 \pm 7^{\mathrm{a})}$ & $281 \pm 46$ & $6.5 \pm 1.3$ & $137 \pm 5$ \\
HP & $165 \pm 5^{* * \mathrm{~b})}$ & $336 \pm 36$ & $3.2 \pm 0.4^{*}$ & $161 \pm 3^{* *}$ \\
HF-corn oil & $157 \pm 3^{* * *}$ & $227 \pm 12$ & $2.0 \pm 0.3^{* *}$ & $225 \pm 10^{* * *}$ \\
HF-MCT & $105 \pm 9^{* * *}$ & $291 \pm 56$ & $1.5 \pm 0.1^{* *}$ & $156 \pm 6^{*}$ \\
Fasted (48 hr) & & & & \\
Control & $116 \pm 6$ & $435 \pm 43$ & $0.04 \pm 0.01$ & $88 \pm 6$ \\
HP & $121 \pm 9$ & $535 \pm 37$ & $0.34 \pm 0.06^{* * *}$ & $92 \pm 10$ \\
HF-corn oil & $128 \pm 8$ & $467 \pm 55$ & $0.21 \pm 0.05^{* *}$ & $112 \pm 9$ \\
HF-MCT & $106 \pm 4$ & $592 \pm 51^{*}$ & $0.33 \pm 0.03^{* * *}$ & $91 \pm 8$ \\
\hline \hline
\end{tabular}

a) Values are means \pm SEM for 8 fed rats and for 6 starved rats.

b) Values significantly different from those of the corresponding control, using $t$-test analysis :

${ }^{*} p<0.05 ;{ }^{* *} p<0.01 ;{ }^{* * *} p<0.001$.

Table 4. Effects of high protein and high fat diets on hepatic glucose-6-phosphatase activity.

\begin{tabular}{lcc}
\hline \multirow{2}{*}{ Groups } & \multicolumn{2}{c}{ G6Pase activity } \\
\cline { 2 - 3 } & $\begin{array}{c}\text { Fed } \\
(\mu \mathrm{mol} / \mathrm{mg}\end{array}$ & $\begin{array}{c}\text { Fasted }(24 \mathrm{hr}) \\
\text { protein } / 10 \mathrm{~min})\end{array}$ \\
\hline Control & $30.4 \pm 1.2^{\mathrm{a})}$ & $35.4 \pm 2.5$ \\
HP & $\left.41.5 \pm 2.7^{* \mathrm{~b}}\right)$ & $34.9 \pm 1.3$ \\
HF-corn oil & $45.4 \pm 2.4^{* * *}$ & $37.8 \pm 2.6$ \\
HF-MCT & $39.0 \pm 2.0^{* *}$ & $37.8 \pm 1.9$ \\
\hline \hline
\end{tabular}

a) Values are means \pm SEM for 8 fed rats and for 6 starved rats.

b) Values significantly different from the control, using $t$-test analysis : $* p<0.02 ;{ }^{* *} p<0.01$; $* * * p<0.001$.

められなかった。

GAT 活性は，拄食ラットの HP 群と HF-MCT 群で 著しく増大した。絶食ラットです同しくくそれら2 群にお いて增大したが, 醭素活性レベルそのるのは摂食ラット のそれより低い活性值であった。対照群と HF-corn oil 群では，拱食，絶食のいずれの条件でむGAT 活性はほ ぼ一定の低い活性値を示し変動しなかった。

興味深いことに高脂肪食の 2 群間で GAT 活性の様相 に明らかな違いが観察された。HF-corn oil 群での糖新 生六進は, GAT 活性の上昇を伴っておらず, 一方, HF-MCT 群ではアラニンからのピルビン酸生成の代 謝経路が活発であることが示唆された。この连いは MCT の代謝に corn oil とは異なる面があることに起

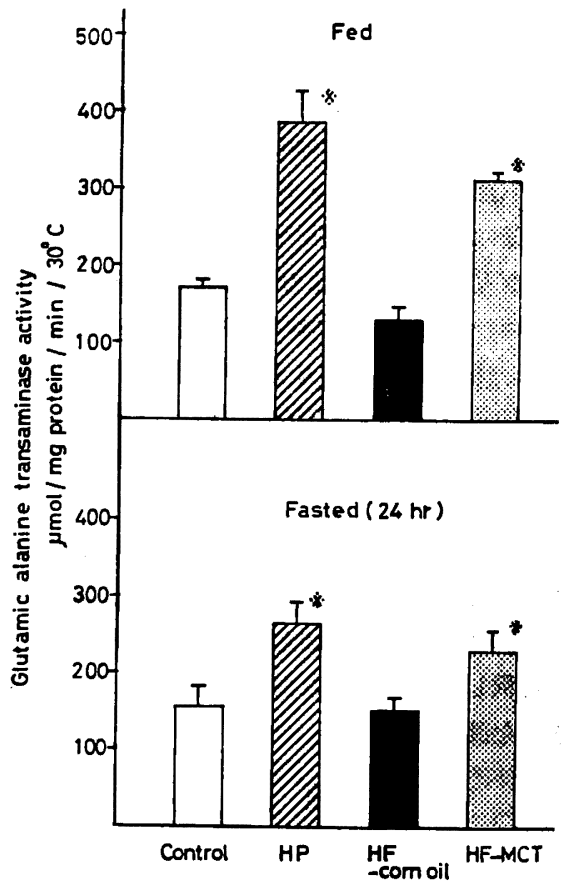

Fig.1. Effects of high protein and high fat diets on glutamic alanine transaminase activity in rat liver.

The results presented represent the means \pm SEM for 8 fed rats and for 6 starved rats.

※ Symbol represents value different from those of other groups (without symbol), respectively as judged by $t$-test analysis $(p<0.01)$. 


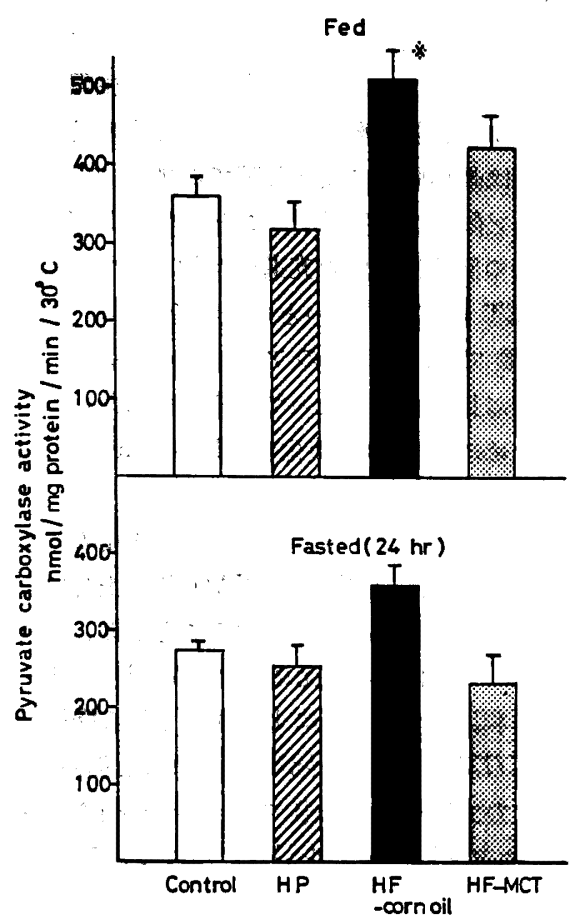

Fig.2. Effects of high protein and high fat diets on pyruvate carboxylase activity in rat liver.

The results presented represent the means \pm SEM for 8 fed rats and for 6 starved rats.

※ Symbol represents value different from that of the control, as judged by $t$-test analysis $(p<$ $0.05)$.

因するすのと思われる。

PC 活性は, 摂食ラットの HF-corn oil 群で有意に增 大した。同じく高脂肪食の HF-MCT 群も対照群に比べ 高い酵素活性の傾向を示したが，HF-corn oil 群ほどの 活性増大にはならなかった。絶食ラットについても HFcorn oil 群は他群に比べ有意に高い活性値を示した。し かし HF-MCT 群では, むはや活性值は高まらなかっ た。このように高脂肪食の条件であっても， corn oil 群 と MCT 群との間では，PC 活性の様相に違いが観察さ れた。HP 群では，摂食，絶食のいずれの場合も PC 活 性は対照群とほぼ同じであり，無糖質による糖新生元進 に対応していなかった。

絶食ラットの各群の PC 活性は, 相対的に掑食ラット に比べ低下した。

PC 活性はアセチル CoA によるアロステリックな活 性化がなされることが知られている23)。したがって，㩒 食ラットに和ける HF-corn oil 群の PC 活性の增大は, この群の肝遊離脂肪酸レベルが高かった事実（Table 3)
Table 5. Effects of high protein and high fat diets on arginase activity.

\begin{tabular}{|c|c|c|}
\hline \multirow[b]{2}{*}{ Groups } & \multicolumn{2}{|c|}{ Arginase activity } \\
\hline & $\underset{(\mu \mathrm{mol} / \mathrm{mg} \mathrm{p}}{\text { Fed }}$ & $\begin{array}{l}\text { asted }(24 \mathrm{hr}) \\
\text { ein } / 10 \mathrm{~min})\end{array}$ \\
\hline Control & $41.7 \pm 2.1^{a)}$ & $45.7 \pm 1.3$ \\
\hline $\mathrm{HP}$ & $\left.71.6 \pm 9.5^{* b}\right)$ & $51.7 \pm 4.0$ \\
\hline HF-corn oil & $28.2 \pm 1.9^{* *}$ & $26.4 \pm 1.0^{* *}$ \\
\hline HF-MCT & $43.0 \pm 1.9$ & $27.5 \pm 1.1^{* *}$ \\
\hline
\end{tabular}

a) Values are means \pm SEM for 8 fed rats and for 6 starved rats.

b) Values significantly different from the control, using $t$-test analysis : $* p<0.01 ;{ }^{* *} p<0.001$.

に合致しておりり，肝アセチル CoA 量も増加しているす のと推察される。

\section{3. 尿素生成系醭素の活性に及ぼす高脂肪食の影嘅}

糖新生六進時の代謝变動に食餉脂肪の種類による違い があるとすれば，糖新生と尿素生成との関連のうえに も，その影䇾があるすのと思われる。そこで，尿素生成 系醭素の arginase 活性を取りあげ観察した（Table 5)。

提食ラットでは，HP 群がどの群よりも高い活性值を 示した。高脂肪食の 2 群のらち, HF-corn oil 群は有意 飞低い arginase 活性であったか， HF-MCT 群は対照 群と同程度の活性値を示した。これら 2 群は高脂肪食と いら同じ条件にありながら， arginase 活性の様相は明 らかに違っていた。飰料掑取量は, むしろ HF-corn oil 群が HF-MCT 群より多くなっているので (Table 2), HF-corn oil 群のタンパク質摂取量は HF-MCT 群より 多いと考えられるが，この群の arginase 活性が低值で あった。

絶食ラットの arginase 活性は, 対照群と HP 群がほ ぼ同し活性值であったが，高脂肪食の 2 群とも有意に低 く，対照群の約 $60 \%$ の活性にとどまった。なお，HF－ MCT 群については，摂食時の arginase 活性が対照群 と同程度の活性值であった（Table 5) のが，絶食によ り活性は低下して HF-corn oil 群の活性レベルとな た。HF-corn oil 群は, 摄食, 絶食のいずれでも一貫し て arginase 活性は低い値であった。これらは，二つの 脂肪の代謝の違いが arginase 活性に影箱を及ぽしてい ることを示唆している。

さらそ，摂食，絶食いずれの場合す，各群の arginase 活性は G6Pase 活性上昇との間に関連はみられなかっ た。試験群のそれぞれは，終局的にクルコース合成が高 まっていても，糖新生過程の代謝変動は慨料組成により 異なり，ひいては糖新生と尿来生成との関連も違ってく ることがわかった。 
試験食群の揕食ラットでは，G6Pase 活性が対照群に 比べ約 $40 \%$ 上昇し, それは高タンパク質, 高脂肪食の 違いとは無関保に一様に上昇した。しかし 24 時間絶食 により，G6Pase 活性は摄食時の $80 \%$ となり，この時 点で試験群と対照群との間に差がみられなくなった。こ の試験群での活性変動をるたらす要因の一つとして, 絶 食時には肝炡の糖新生基質量が摂食時に比べて減少2224) していることが推察される。

各群の絶食時血糖値はほぼ同じであったが，絶食時の 旰クリリーグン量は，值そのものは非常に小さいが，試 験群が対照群の $5 \sim 8$ 倍量 (Table 3) であった。これは 明らかに無桾質食の影響5200を示しており，この絶食時 の肝グリューゲン量の高値は, 試験群での肝グリコーゲ ン利用の減少を意味するのかるしれない。

試験群の 3 群では無糖質食により糖新生が六進する条 件にあり，摂食時の G6Pase 活性が一様に上昇したにも かかわらず，GAT，PC の両活性は，高脂肪群之高タン パク質群との間で同じ様相を示さなかった。とくに HFcorn oil 群のそれらは, 高タンパク質群とは大きな違い を示した。さらに 24 時間絶食後にも，GAT，PC の両 活性は侤然として試験群間で違いが観察された。これら はグルコースの血中放出が高まっていても，その糖新生 経路の代謝六進の様相が，食餌条件によって異なること を示唆している。

ピルビン酸のミトコンドリアへの移行は，エネルギー 利用だけでなく糖新生にとっても重要な役割を演じてお ク，高タンパク質食 ${ }^{25226) や タ ル カ コ ゙ ン 27) に よ り ヒ ゚ ル ヒ ゙ ン ~}$ 酸のミトコンドリアへの移行が亢進することが報告され ている。高タンパク質食の動物では，血中グルカコン值

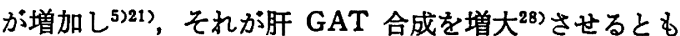
言われている。Rémésy ら²)よると，高タンパク質-無 糖質食ラットの肝ピルビン酸量は減少するので, HP 群 ではクルカコン分泌を介しての GAT 活性の上昇の結 果, ピルビン酸生成が增加してミトコンドリアへの移行 が高まり，糖新生へのその利用も増大するものと思われ る。

一方, 高脂肪食群では，脂肪源が長鎖脂肪か中鎖脂肪か の違いにより糖新生系䣼素活性の上昇に違いがみられた (Fig.1，2)。摂食ラットの HF-corn oil 群の PC 活性 は著明に增大したが，これはこの群の肝遊離脂肪酸量の 増加 (Table 3) と関連していると思われる。実際に肝の フセチル CoA 量を測定していないので肝遊離脂肪酸量 から類推すると, HF-corn oil 群のアセチル CoA 量が 增加してPCの活性化が高まったのであろう。HF-MCT 群では, HF-corn oil 群ほどに PC 活性は高まらず, む
しろ GAT 活性が増大した。この現象は捸食, 絶食のい ずれの条件でも観察され，むしろ高タンパク質群に近い バターンを示した。これは MCT の特異な生理作用に起 因した何らかの代謝変動が影留しているものと思われ る。MCT は長鎖脂肪に比へ肝矌でのアセチル CoA, $\mathrm{CO}_{2}$ ，ヶトン体への異化が早いことや10)， $\mathrm{MCT}$ 投与に よる肝臓での脂肪酸合成の充進 ${ }^{29}$ が知られている。この ように MCT の代謝が早いといら特色から類推して, HF-MCT 群では, 肝贜中のアセチル CoA 量が HFcorn oil 群に比べ少なくなっているのではないかと考え る。そのために PC の活性化が，HF-corn oil 群注ど 起こらなかったものと思われる。

ミトコンドリア内オキザロ酰酸の炭素骨格の細胞質へ の移動は, 細胞質内の $\mathrm{NADH} / \mathrm{NAD}$ 比の上昇により抑 制され，その結果糖新生は低下することが報告されてい

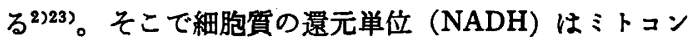
ドリアへ移され電子伝達系により酸化される機構が働い $\tau, \mathrm{NADH} / \mathrm{NAD}$ 比の上昇か改善されると糖新生は促 進し ${ }^{30)}$ ，その機構にリンゴ酸-アスパラギン酸シャトル と $\alpha$ ーグリセロン酸シャトルが考えられている30131)。

Rémésy らの報告2)によると, 高タンパク質-無糖質 食のラットでは肝細胞中グルタミン酸が増加してアスパ ラギン酸が減少しており，それらは糖新生におけるフス バラギン酸の利用增大を示唆している。したがって HP 群の摂食ラットでは,リンコ酸ーフスパラギン酸シャト ルが亢進して，オキザロ酢酸の炭素骨格はフスパラギン 酸の形で細胞質への移行が増加し，流入した細胞質内フ スパラギン酸は $\alpha$-ケトグルタール酸とのフミノ基転移 反応に用いられるほかに，尿素サイクルにはいりフ ル酸からのリンゴ酸生成が増加》して糖新生を六進させ ているのであろう。本研究では細胞質とミトコンドリア を一緒にして arginase 活性を観察している（Table 5) が, この群での細胞質内 arginase 活性の上昇の可能性 が十分に考えられる。さらに，HP 群ではリンゴ酸一フ スパラギン酸シャトル六進のためミトュンドリアのクル タミン酸量が増加225332) して, PC 活性が 抑制（Fig.2） された可能性 ${ }^{33)}$ す考えられる。

一方，高脂肪食では，HF-corn oil が群の糖新生系䤃 素の活性上昇に対し arginase 活性の増大を伴って扰ら ず, しかし肝遊離脂肪酸量が増加していた（Table 3)。 この事実から推察すると，HF-corn oil 群では，高タン パク質群の場合のようにリンゴ酸ーアスパラギン酸シャ トルの進行は考えにくい。それよりは，脂肪酸の酸化に 伴らミトコンドリフ内のアセチル CoA 量の增加36がオ キザロ酢酸の炭素骨格をアスパラギン酸よりはリンコ酸 の形で細胞貿へ流出させて，糖新生系が進行するのでは ないかと考える。すしそらであれば，この群の糖新生立 
進時に arginase 活性上昇を伴わない可能性は十分にあ

るといえる。

HF-MCT 群では摄食ラットの arginase 活性は HFcorn oil 群に比べ有意任高まっていた（Table 5)。ゆえ に尿素生成系醇素活性と糖新生六進との関 連は, HFcorn oil 群の場合とは明らかに異なっている。この違い が何によって引き起こされているのかはよくわからな い。しかしこの二つの脂肪の代謝の違い(10)か関連してい るすのと思われる。 MCT の代謝特性がもたらすミトコ ンドリフ内の環境変化が何らかのかかわりをむつものと 考える。HF-MCT 群の絶食ラットでは, arginase 活性 はHF-corn oil 群と同レベルに低下してすはや絶食時 には MCT の影響はみられなくなった。

高脂肪食群の結果から示唆されることは，脂肪酸の酸 化の程度により, 糖新生元進と尿素生成との関連が違っ てくるといらことである。さらに本研究により，高脂肪 食(長鎖脂肪)による糖新生六進の代謝変動は, 高タンパ ク質食のそれとは異なることが羿められた。そのメカニ ズムの詳細について今後さらに検討の必要がある。

\section{要 約}

高脂肪食による糖新生亢進時の代謝変動は高タンパク 質のそれとは異なり，ひいては糖新生と尿素生成との関 連にる違いをすたらすかどらかを検討した。

漓乳直後の雄ラットを，無糖質からなる高タンパク質 食および高脂肪食 (corn oil と MCT)の 3 群の試験群と 対照群(高糖質食)に分け, 10日間飼育し次の結果を得た。

1）揕食ラットでは，G6Pase 活性はどの試験群です 增大した。しかし GAT, PC, arginase 活性は各群間一 様ではなかった。すなわち，(1) HP 群では，GAT と arginase 活性が上昇したが，PC 活性は增大しなかっ た。(2) 高脂肪食群の corn oil 群では, PC 活性が著し く增大したが， GAT と arginase 活性は增大しなかっ た。MCT 群では PC 活性は増大せず，むしろ GAT 活 性が增大した。

2）24時間絶食により，3 試験群の G6Pase 活性は 摄食ラットの約 $80 \%$ に低下し，対照群とほぽ同し活性 レベルとなった。しかし各群間の GAT，PC 活性の違い は，摂食ラットの場合のそれと同じであった。高脂肪食 の 2 群とす絶食時の arginase 活性は他群に比べ低值で あった。

以上より，高脂肪（長鎖）食による糖新生え進過程の 代謝変動は，高タンパク質のそれとは異なり，尿素生成 楼素活性の增加を伴っていないことがわかった。

本研究の概要は昭和 55 年 8 月, 第 34 回日本栄差・食 䊓学会総会で発表した。

\section{文博}

1) Kusaka, M. and Ui, M. : Am. J. Physiol., 232, E 145 (1977)

2) Rémésy, C. and Demigné, C. : J. Nutr., 112, 60 (1982)

3) Ross, B.D., Hems, R. and Krebs, H.A. : Biochem. J., 102, 942 (1967)

4) Evans, R.M. and Scholz, R.W. : J. Nutr., 101, 1127 (1971)

5) Eisenstein, A.B., Strack, I. and Steiner, A. : Diabetes, 23, 869 (1974)

6) Takase, S., Morimoto, A., Moriuchi, S. and Hosoya, N. : J. Nutr. Sci. Vitaminol., 27, 219 (1981)

7) Krebs, H.A., Lund, P. and Stubbs, M. : Gluconeogenesis (Hanson, R.W. and Mehlman, M.A., eds.), 269 (1967), John Wiley \& Sons, Inc., New York

8) Sugano, T., Shiota, M., Khno, H. and Shimada, M. : J. Biochem., 91, 1917 (1982)

9) Meijer, A.J., Gimpel, J.A., Deleeuw, G., Tishler, M.E., Tager, J.M. and Williamson, J.R. : J. Biol. Chem., 253, 2308 (1978)

10) Greenberger, N.J. and Skillman, T.G. : New Engl. J. Med., 280, 1045 (1969)

11) Segal, H.L. and Washko, M.E. : J. Biol. Chem., 234, 1937 (1959)

12) Fiske, C. and SubbaRow, Y.: J. Biol. Chem., 66, 375 (1925)

13) Segal, H.L., Beattie, D.S. and Happer, S. : J. Biol. Chem., 237, 1914 (1962)

14) Utter, M.F. and Keech, D.B. : J. Biol. Chem., 238, 2603 (1963)

15) Schimke, R.T. : J. Biol. Chem., 237, 459(1962)

16) Lowry, O.H., Rosebrough, N.J., Farr, A.L. and Randall, R.J. : J. Biol. Chem., 193, 265 (1951)

17) Dahlquist, A. : Anal. Biochem., 7, 18 (1964)

18）久城英人, 高野圭以, 會山浩吉, 福井 厳: 臨床 病理, 18, 833 (1970)

19) Seifter, S., Dayton, S., Novic, D.B. and Muntwyler, E. : Arch. Biochem., 25, 191 (1950)

20) Zaragoza, Z. and Felber, J.P. : Horm. Metab. Res., 2, 323 (1970)

21) Eisenstein, A. B. and Strack, I. : Proc. Soc. Exp. Biol. Med., 158, 578 (1978)

22) Unger, R.H., Eisenstraut, A.M. and Madison, L.L. : J. Clin. Invest., 42, 1031 (1963)

23) Scrutton, M.C. and Utter, M.F. : Annu. Rev. Biochem., 37, 249 (1968)

24) Metzger, B.E., Hare, J.W. and Freinkel, N.: J. Clin. Endocrinol., 33, 869 (1971)

25) Rémésy, C., Demigné, C. and Aufrére, J. : Biochem. J., 170, 321 (1978)

26) McDaniel, H.G. : Am. J. Physiol., 236, E 501 (1979)

27) Halestrap, A.P., Scott, R.D. and Thomas, A.P. : Int. J. Biochem., 11, 97 (1980)

28) Rosen, F., Roberts, H.R. and Nichol, C.A. : J. Biol. Chem., 234, 476 (1959)

29) Takase, S., Morimoto, A., Nakanishi, M. and Muto, Y.: J. Nutr. Sci. Vitaminol., 23, 43 (1977)

30) Dawson, A.G.: Trends Biochem. Sci., 4, 171 
(1979)

31）菅野 司, 塩田昌一：代謝，21，49（1984）

32) Meijer, A.J. and Williamson, J.R. : Biochem. Biophys. Acta, 333, 1 (1974)

33) Scrutton, M.C. and White, M.D. : J. Biol.
Chem., 246, 5405 (1974)

34) Walajtys-Rode, E., Coll, K.E. and Williamson, J.R. : J. Biol. Chem., 254, 11521 (1979)

（昭和 59 年 6 月 13 日受理） 